\title{
Tipe peneluran, pengaruh lama ketiadaan inang, dan pakan terhadap keragaan reproduksi parasitoid Anagrus nilaparvatae Pang et Wang (Hymenoptera: Mymaridae)
}

\author{
Egg maturation, effect of host deprivation, and feeding toward \\ reproductive performance of egg parasitoid Anagrus nilaparvatae \\ Pang et Wang (Hymenoptera: Mymaridae)
}

\author{
Nurullah Asep Abdilah ${ }^{{ }^{*}}$, Tri Atmowidi' ${ }^{2}$ Damayanti Buchori ${ }^{3}$ \\ ${ }^{1}$ Program Studi Bologi, Fakultas Sains dan Farmasi Universitas Mathla'ul Anwar \\ Jalan Raya Labuan Km 23, Cikaliung Saketi, Pandeglang 42273 \\ ${ }^{2}$ Departemen Biologi, Fakultas Matematika dan Ilmu Pengetahuan Alam, \\ Institut Pertanian Bogor, Jalan Agatis, Kampus IPB Dramaga, Bogor 16680. \\ ${ }^{3}$ Departemen Proteksi Tanaman, Fakultas Pertanian, Institut Pertanian Bogor \\ Jalan Kamper, Kampus IPB Dramaga, Bogor 16680.
}

(diterima Desember 2014, disetujui November 2015)

\begin{abstract}
ABSTRAK
Anagrus nilaparvatae Pang et Wang (Hymenoptera: Mymaridae) adalah parasitoid telur utama wereng coklat, Nilaparvata lugens Stal (Hemiptera: Delphacidae). Tujuan penelitian ini adalah mempelajari tipe peneluran, pengaruh lama ketiadaan inang dan pakan terhadap keragaan reproduksi parasitoid $A$. nilaparvatae. Penentuan tipe peneluran dilakukan berdasarkan rancangan acak lengkap (RAL) dengan 7 perlakuan dan masing-masing perlakuan diulang sebanyak 15 kali. Satu individu imago betina A. nilaparvatae umur $0,1,2,3,4,5$, dan 6 jam dibedah abdomennya untuk diamati jumlah telur yang matang (sudah memiliki pedisel). Penentuan pengaruh lama ketiadaan inang dilakukan berdasarkan RAL dengan 6 perlakuan dan masing-masing perlakuan diulang 15 kali. Tiap satu individu betina dewasa $A$. nilaparvatae yang baru muncul diberi pakan larutan madu 10\% atau air selama 3, 6, 9, 12, dan 18 jam kemudian diberikan inang (telur $N$. lugens) setiap hari sampai parasitoid mati. Hasil penelitian menunjukkan bahwa A. nilaparvatae termasuk kelompok proovigenik dengan $75 \%$ telur yang sudah matang diawal kehidupan dewasanya. Pematangan telur A. nilaparvatae sudah diawali sejak parasitoid keluar dari inangnya sebagai imago (proovigenik) dengan telur yang sudah matang sebanyak $75 \%$ dari potensi produksi telur. Ketiadaan inang menyebabkan menurunnya keperidian dan tingkat parasitisasi A. nilaparvatae. Penurunan keperidian dan tingkat parasitisasi diduga karena perubahan perilaku akibat ketiadaan inang. Lama hidup tertinggi terjadi pada periode ketiadaan inang selama 9 jam dan terendah selama 18 jam.
\end{abstract}

Kata kunci: agens hayati, Nilaparvata lugens, proovigenik

\begin{abstract}
Anagrus nilaparvatae Pang et Wang (Hymenoptera: Mymaridae) is a major egg parasitoid of brown planthopper, Nilaparvata lugens Stal (Hemiptera: Delphacidae). The purpose of this study was to examine the type of nesting, the effect of host deprivation and feeding on the reproductive
\end{abstract}

\footnotetext{
*Penulis korespondensi: Nurullah Asep Abdilah. Fakultas Sains dan Farmasi Universitas Mathla’ul Anwar (UNMA) Pandeglang, Jalan Raya Labuan Km 23, Cikaliung Saketi, Pandeglang 42273. Tel/Faks: 0253-401773, Email: nurullah.asep@gmail.com.
} 
performance of parasitoid. Determination of the type of nesting was done by dissecting females of A. nilaparvatae upon emerging. Adult females aged $0,1,2,3,4,5$, and 6 hours were killed in the freezer. Abdominal of wasp was dissected by micro pin. Mature egg of wasp were calculated and documented. Treatment of host deprivations were conducted by feeding $10 \%$ honey solution and depriving female parasitoids of host for 3, 6, 9, 12, and 18 hours consecutively. After treatments, female parasitoids were given hosts every day until the parasitoids died. Another group of parasitoids were given with water and treated with the same lenght of deprivation period. Results showed that the A. nilaparvatae nesting type's is proovigenic. The egg maturation of parasitoid has been initiated since it first emerge with $75 \%$ mature eggs of potential fecundity. In the conditions provided $10 \%$ honey solution or water as feed, reproductive performance of A. nilaparvatae decreased with increasing duration of host deprivation period, include realized fecundity, parasitization rate, and longevity of female wasp. The decline in the reproductive performance was done by host deprivation for 9 to 18 hours. Longevity of female wasps varied from one to three days, with higher and lower values consecutively for 9 and 18 hours of host deprivation period.

Key words: biological agents, proovigenic, Nilaparvata lugens

\section{PENDAHULUAN}

Anagrus nilaparvatae Pang et Wang (Hymenoptera: Mymaridae) adalah parasitoid telur utama yang menyerang telur wereng coklat, Nilaparvata lugens Stal (Hemiptera: Delphacidae). Sifatnya yang polifag, fekunditas yang cukup tinggi dan didukung dengan siklus hidup yang singkat, yaitu 10-13 hari menjadikan A. nilaparvatae dapat digunakan sebagai agens pengendali $N$. lugens di lapangan (Meilin et al. 2012). Diani et al. (1992) melaporkan bahwa kemampuan Anagrus spp. memarasit telur $N$. lugens pada tanaman padi mencapai 38\%. Selain itu, parasitoid Anagrus spp. mampu memarasit wereng hijau (Nephotettix spp.), wereng punggung putih (Sogatella furcifera (Horváth)), Laodelphax striatellus (Fallén), Empoasca fabae (Harris), Typhlocyba pomaria McAtee, Dikrella cruentata (Gillette), dan Circulifer tenellus (Baker) (Sahad \& Hirashima 1984). Pengendalian N. lugens sebelumnya masih banyak mengandalkan insektisida kimia yang diterapkan secara intensif sehingga menimbulkan banyak dampak negatif terutama terhadap lingkungan (Kartohardjono 2011). Penggunaan $A$. nilaparvatae sebagai agens pengendali hayati dapat menjadi alternatif pengendalian $N$. lugens di lapangan, namun tetap aman terhadap lingkungan.

Pengendalian serangga hama dengan memanfaatkan parasitoid dipengaruhi oleh perilaku reproduksi parasitoid betina. Keberhasilan reproduksi parasitoid betina ditentukan antara lain oleh tipe parasitoid dan ketersediaan inang (Drost \& Carde 1992). Parasitoid tipe proovigenik di awal kehidupan dewasanya sudah memiliki telur yang 128 matang dan siap diletakkan pada inang (Mutitu et al. 2013). Parasitoid synovigenik memerlukan waktu untuk mematangkan telurnya. Pematangan telur tersebut memerlukan pakan inang dan noninang (madu) (Savino et al. 2012). Pasokan pakan madu pada parasitoid proovigenik umumnya tidak digunakan untuk memproduksi atau mematangkan telur melainkan untuk meningkatkan lama hidup (Cronin \& Strong 1990; Mutitu et al. 2013). Parasitoid synovigenik melakukan resorpsi telur (oosorption) ketika kondisi stres, seperti suhu rendah dan atau kekurangan pakan (Santolamazza \& Cordero 2003), dan ketiadaan inang (Kapranas \& Luck 2008) untuk menghemat energi. Parasitoid synovigenik akan memproduksi kembali telur matang ketika kondisi sudah menguntungkan (Papaj 2000). Parasitoid proovigenik umumnya tidak memiliki kemampuan resorpsi telur (Kant et al. 2013). Parasitoid proovigenik, Trichogramma brassicae Bezdenko (Hymenoptera: Trichogrammatidae) melakukan resorpsi telur dalam kondisi ketiadaan inang, namun tidak mampu untuk memproduksi kembali telur matang setelah resorpsi (Fleury \& Bouletreau 1993). Perbedaan tipe tersebut akan mempengaruhi perilaku pencarian inang dan oviposisi oleh parasitoid di lapangan dan berdampak terhadap strategi pengendalian hayati yang diterapkan.

Ketersediaan inang di alam sangat fluktuatif. Akbar \& Buchori (2012) melaporkan bahwa lama ketiadaan inang dapat menurunkan kemampuan reproduksi parasitoid Snellenius manilae Ashmead (Hymenoptera: Braconidae). Semakin lama $S$. manilae tidak menemukan inang maka semakin sedikit jumlah telur yang diproduksi. Selain itu, 
ketiadaan inang mampu meningkatkan lama hidup imago $S$. manilae betina, tetapi tidak diikuti dengan peningkatan produktivitas telur. Namun, Tarla (2011) melaporkan sebaliknya bahwa ketiadaan inang tidak mempengaruhi periode oviposisi dan lama hidup parasitoid telur Trissolcus grandis Thompson (Hymenoptera: Scelionidae). Berbedanya hasil tersebut disebabkan oleh perbedaan tipe parasitoid, yakni $S$. manilae termasuk synovigenik (Akbar \& Buchori 2012), sedangkan T. grandis merupakan proovigenik (Tarla 2011). Sampai saat ini belum ada publikasi yang mengkaji perihal keragaan reproduksi parasitoid A. nilaparvatae terkait dengan ketiadaan inang dan pakan. Pembuktian terhadap tipe peneluran dari parasitoid A. nilaparvatae belum pernah dilakukan. Padahal, keragaan reproduksi parasitoid dapat dipengaruhi oleh pematangan telur, kualitas pakan, dan ketersediaan inang (Fleury \& Bouletreau 1993).

Tujuan penelitian ini adalah mempelajari tipe peneluran, pengaruh lama ketiadaan inang dan pakan terhadap keragaan reproduksi parasitoid $A$. nilaparvatae.

\section{BAHAN DAN METODE}

Penelitian dilaksanakan pada bulan Juli 2013 sampai Juni 2014 di Laboratorium Pengendalian Hayati, Departemen Proteksi Tanaman, Fakultas Pertanian, Institut Pertanian Bogor (IPB). Pembedahan abdomen parasitoid dan jaringan padi dilakukan di Laboratorium Terpadu, Departemen Biologi, Fakultas Matematika dan Ilmu Pengetahuan Alam, IPB.

\section{Penentuan tipe peneluran $A$. nilaparvatae}

Penelitian dilakukan berdasarkan rancangan acak lengkap (RAL) dengan 7 perlakuan dan diulang sebanyak 15 kali dengan masingmasing perlakuan menggunakan imago betina A. nilaparvatae sebanyak satu individu. Imago betina $A$. nilaparvatae umur $0,1,2,3,4,5$, dan 6 jam segera dimatikan dalam freezer. Penentuan umur sampel $A$. nilaparvatae tersebut didasarkan pada lama hidup $A$. nilaparvatae hanya berkisar 1-2 hari (Xiang et al. 2008). Imago betina $A$. nilaparvatae yang sudah mati diletakkan di atas gelas objek dan ditetesi air secukupnya (satu tetes). Abdomen $A$. nilaparvatae selanjutnya dibedah menggunakan jarum mikro bertangkai yang diamati dengan mikroskop stereo Olympus SZ51. Imago betina $A$. nilaparvatae yang telah dibedah abdomennya diamati ada atau tidaknya telur matang dalam ovarinya yang dilakukan dengan bantuan mikroskop compound Olympus BX51. Telur matang A. nilaparvatae yang teramati dihitung jumlahnya dan didokumentasikan.

\section{Pengaruh lama ketiadaan inang dan pakan terhadap keragaan reproduksi parasitoid $A$. nilaparvatae}

Penyiapan inang. Penelitian dilakukan berdasarkan RAL dengan 6 perlakuan ketiadaan inang dan masing-masing perlakuan diulang 15 kali. Satu bibit padi umur 2 minggu diberi kapas pada bagian akarnya, kemudian dibungkus dengan alumunium foil $(1 \mathrm{~cm} \times 6 \mathrm{~cm})$. Kapas diberi air agar bibit padi tetap segar. Ujung bibit padi dipotong agar panjang bibit sama dengan panjang tabung reaksi $(10 \mathrm{~cm})$ (Meilin et al. 2012). Bibit padi dimasukan ke dalam tabung reaksi dengan bagian akar berada pada mulut tabung. Bibit padi disediakan sebanyak perlakuan. Tiga individu imago $N$. lugens gravid dimasukan ke dalam tabung reaksi yang telah berisi bibit padi (umur 2 minggu), selanjutnya ditutup dengan kain kasa dan diikat dengan karet gelang. Imago $N$. lugens dibiarkan bertelur pada bibit padi selama dua hari kemudian dikeluarkan. Bibit padi umur 2 minggu yang telah diteluri $N$. lugens selama 2 hari siap digunakan untuk perlakuan.

Perlakuan ketiadaan inang pada parasitoid. Parasitoid A. nilaparvatae yang baru keluar dari inang diberi pakan larutan madu $10 \%$ dengan cara dioleskan pada alumunium foil $(0,5 \mathrm{~cm} \times 4 \mathrm{~cm})$ yang dimasukan dalam tabung reaksi. Imago parasitoid betina $A$. nilaparvatae selanjutnya tidak diberikan inang selama 0 (kontrol), 3, 6, 9, 12, dan 18 jam. Penentuan waktu lama ketiadaan inang didasarkan pada lama hidup A. nilaparvatae yang hanya berkisar 1-2 hari. Imago parasitoid $A$. nilaparvatae ( 1 individu) yang telah diperlakukan ketiadaan inang dimasukan ke dalam masingmasing tabung reaksi berisi bibit padi yang telah diinfestasi telur $N$. lugens. Sementara itu, terdapat 
kelompok parasitoid A. nilaparvatae dengan perlakuan ketiadaan inang yang sama, namun diberi pakan air. Bibit padi diganti dengan bibit padi baru yang juga telah diinfestasi telur $N$. lugens sampai imago parasitoid $A$. nilaparvatae mati. Pergantian bibit padi dilakukan setelah 24 jam.

Pengamatan meliputi jumlah telur yang diletakkan parasitoid dalam inang di hari pertama dan kedua, keperidian (realized fecundity), tingkat parasitisasi, potensi produksi telur (potential fecundity), telur yang tersisa dalam ovari, dan lama hidup imago parasitoid betina. Parasitisasi diamati dengan cara membedah jaringan bibit padi di akhir pengamatan untuk melihat telur $N$. lugens yang terparasit. Telur $N$. lugens terparasit berwarna jingga kemerahan. Jumlah telur yang diletakkan parasitoid ditentukan dengan cara menjumlahkan imago parasitoid yang muncul dari inang dengan pradewasa parasitoid (prepupa, praimago) yang mati dalam inang. Keperidian merupakan jumlah telur yang diletakkan parasitoid dalam inang seumur hidup parasitoid, meliputi jumlah telur yang diletakkan di hari pertama dan hari kedua. Tingkat parasitisasi parasitoid ditentukan dengan membandingkan jumlah telur $N$. lugens terparasit terhadap total telur $N$. lugens. Jumlah telur $N$. lugens terparasit ditentukan dengan cara menjumlahkan keturunan parasitoid, yakni imago parasitoid yang muncul dan pradewasa parasitoid yang mati dalam inang (telur $N$. lugens). Total telur $N$. lugens ditentukan dengan cara menjumlahkan antara nimfa $N$. lugens yang muncul, telur $N$. lugens yang tidak menetas dan keturunan parasitoid (imago parasitoid yang muncul dan pradewasa parasitoid yang mati dalam inang) sehingga perhitungan tingkat parasitisasi parasitoid ditentukan mengacu pada Meilin (2012).

Tingkat parasitisasi $=\frac{\sum \text { Keturunan parasitoid }}{\begin{array}{c}\sum \text { Telur N.lugenstidakmenetas }+\sum \text { Nimfa } \\ \text { N.lugens }+\sum \text { Keturunan parasitoid }\end{array}}$

Potensi produksi telur merupakan keseluruhan telur yang mampu diproduksi parasitoid seumur hidupnya, meliputi telur yang diletakkan dalam inang seumur hidup (keperidian) dan telur yang tidak diletakkan dalam inang (tersisa dalam ovari). Telur yang tidak diletakkan parasitoid dalam inang ditentukan dengan cara menghitung telur yang berada dalam ovari setelah parasitoid mati sehingga perhitungan potensi produksi telur parasitoid mengacu pada Meilin (2012).

Potensi produksi telur $=$ Keperidian $+\sum_{\text {dalam ovari }}^{\sum \text { Telur yang tersisa }}$

Telur yang tersisa dalam ovari ditentukan dengan cara membedah abdomen parasitoid yang sudah mati di akhir perlakuan. Pembedahan dilakukan dengan merobek abdomen betina parasitoid. Betina A. nilaparvatae yang sudah mati diletakkan di atas gelas objek yang sebelumnya telah ditetesi air (satu tetes) selanjutnya dibedah abdomennya menggunakan jarum mikro bertangkai di bawah mikroskop stereo Olympus SZ51. Setelah abdomen dibedah kemudian diamati di bawah mikroskop compound Olympus BX 51 yang sudah dilengkapi dengan kamera beserta monitornya. Telur yang teramati dihitung jumlahnya dan didokumentasikan. Lama hidup parasitoid betina ditentukan sejak awal kemunculannya menjadi imago hingga mati.

\section{Analisis data}

Data yang diperoleh dianalisis dengan uji analisis ragam (one way ANOVA) dilanjutkan dengan uji Tukey. Data yang distribusinya tidak normal ditransformasi sebelum dianalisis. Data jumlah telur matang dalam ovari ditransformasi kuadrat. Data total parasitisasi (pakan air) ditransformasi akar ke sqrt (variabel). Data total nimfa $N$. lugens yang mati dalam padi ditransformasi logaritma natural dilanjutkan transformasi kebalikan akar. Data jumlah telur yang diletakkan dan tingkat parasitisasi di hari kedua serta lama hidup imago parasitoid betina dianalisis menggunakan uji Kruskal Wallis dilanjutkan dengan uji Mann-Whitney. Tingkat signifikansi yang digunakan sebesar 0,05 . Pengolahan data menggunakan program SPSS 16.

\section{HASIL}

\section{Tipe peneluran $A$. nilaparvatae}

Telur matang $A$. nilaparvatae berbentuk elips (elongate) dan dilengkapi dengan pedunculus yang panjang (Gambar 1). Parasitoid betina $A$. nilaparvatae memiliki telur yang sudah matang dalam ovarinya rata-rata $30,67 \pm 4,35$ telur di awal kehidupan dewasanya dan setelah 3 jam meningkat menjadi rata-rata $37,07 \pm 5,18$ telur, walaupun telur yang belum matang tidak terdeteksi (telur 
belum matang tidak teramati selama pembedahan ovarium imago parasitoid). Jumlah telur matang A. nilaparvatae selanjutnya cenderung konstan. Jumlah telur yang terdapat dalam ovari $A$. nilaparvatae dari 0 hingga 2 jam tidak berbeda, yakni berturut-turut rata-rata $30,67 \pm 4,35$ telur, $30,73 \pm 2,93$ telur, dan $30,93 \pm 5,23$ telur. Peningkatan secara signifikan terjadi pada 3 dan 4 jam, yakni berturut-turut rata-rata $37,07 \pm 5,18$ telur dan 37,13 $\pm 5,37$ telur. Jumlah telur dalam ovari A. nilaparvatae selanjutnya terus meningkat pada jam-jam berikutnya ( 5 dan 6 jam) walaupun tidak berbeda nyata, yakni secara berturut-turut rata-rata 40,07 $\pm 2,68$ telur dan 40,53 $\pm 2,56$ telur (Gambar 2).

Parasitisasi $A$. nilaparvatae yang diberi pakan larutan madu $10 \%$

Hasil penelitian menunjukkan bahwa lama ketiadaan inang mempengaruhi jumlah telur yang diletakkan $A$. nilaparavatae pada inang di hari pertama $(\mathrm{F}=23,52, \mathrm{P} \leq 0,001, \mathrm{~N}=90)$ dan kedua $\left(\chi^{2}=30,12, \mathrm{P} \leq 0,001, \mathrm{~N}=90\right)$, keperidian $(\mathrm{F}=$ $31,45, \mathrm{P} \leq 0,001, \mathrm{~N}=90)$, tingkat parasitisasi di hari pertama $(F=20,94, P \leq 0,001, N=90)$ dan kedua $\left(\chi^{2}=28,11, \mathrm{P} \leq 0,001, \mathrm{~N}=90\right)$, total parasitisasi $(\mathrm{F}=36,53, \mathrm{P} \leq 0,001, \mathrm{~N}=90$,$) , jumlah telur yang$ tersisa dalam ovari $(\mathrm{F}=46,40, \mathrm{P} \leq 0,001, \mathrm{~N}=90)$ serta potensi produksi telur $(\mathrm{F}=7,84, \mathrm{P} \leq 0,001$, $\mathrm{N}=90$ ). Semakin lama $A$. nilaparvatae tidak mendapatkan inang dapat menurunkan jumlah telur yang diletakkan $A$. nilaparvatae dalam inang di hari pertama dan kedua, keperidian, serta tingkat parasitisasinya terhadap inang sehingga jumlah telur yang tersisa dalam ovari A. nilaparvatae menjadi semakin banyak (Tabel 1 dan 2). Keperidian dan tingkat parasitisasi A. nilaparvatae mulai menurun setelah 3 jam tidak mendapatkan inang dan semakin menurun seiring dengan semakin lamanya $A$. nilaparvatae

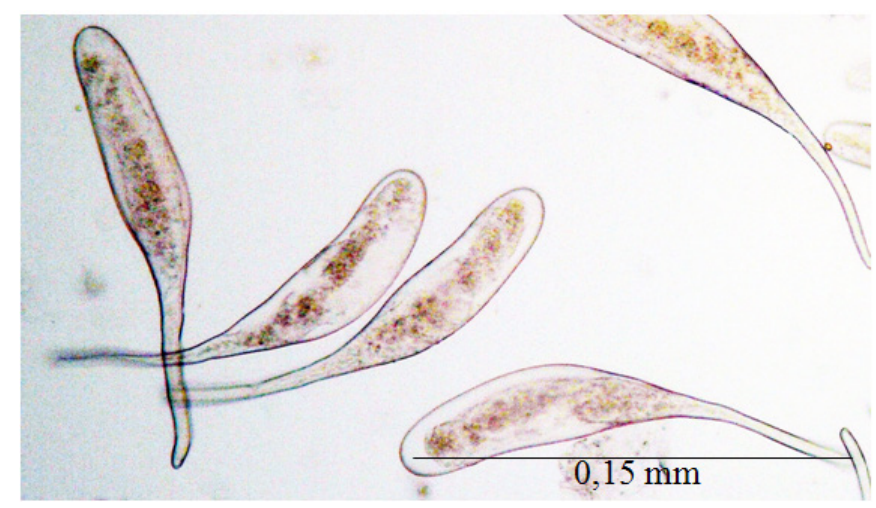

Gambar 1. Telur matang parasitoid Anagrus nilaparvatae.

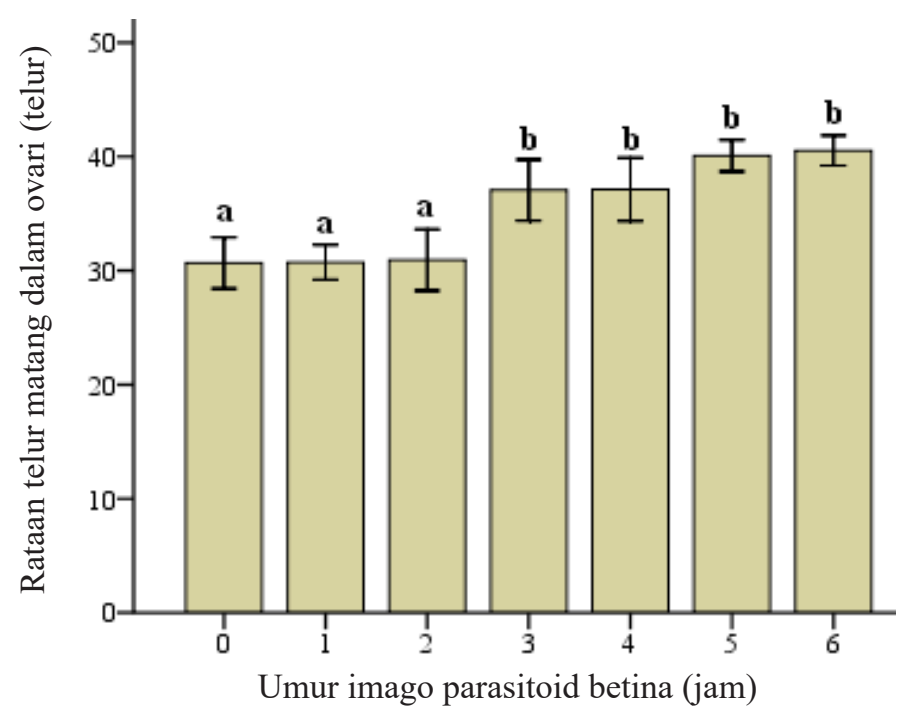

Gambar 2. Rata-rata jumlah telur matang dalam ovari Anagrus nilaparvatae. Huruf yang sama di atas kelompok diagram tidak berbeda nyata pada taraf 5\% (uji Tukey). 
tidak mendapatkan inang. Tingkat parasitisasi tertinggi ditunjukan pada parasitoid yang tidak mendapatkan inang selama 3 jam dan terendah selama 18 jam. Jumlah telur yang diletakkan $A$. nilaparvatae pada telur $N$. lugens lebih banyak di hari pertama dibandingkan dengan hari kedua sehingga tingkat parasitisasi di hari pertama lebih tinggi dibandingkan dengan hari kedua (Tabel 1). Potensi produksi telur $A$. nilaparvatae meningkat setelah 3 jam A. nilaparvatae tidak mendapatkan inang selanjutnya potensi produksi telur cenderung konstan (tetap) (Tabel 2).

\section{Parasitisasi $A$. nilaparvatae yang diberi pakan air}

Lama ketiadaan inang mempengaruhi jumlah telur yang diletakkan $A$. nilaparvatae dalam inang di hari pertama $(\mathrm{F}=33,85, \mathrm{P} \leq 0,001, \mathrm{~N}=90)$ namun tidak di hari kedua $\left(\chi^{2}=9,41, \mathrm{P}=0,093, \mathrm{~N}\right.$ $=90)$, keperidian $(\mathrm{F}=35,04, \mathrm{P} \leq 0,001, \mathrm{~N}=90)$, tingkat parasitisasi di hari pertama $(\mathrm{F}=25,19, \mathrm{P} \leq$ $0,001, \mathrm{~N}=90)$ namun tidak di hari kedua $\left(\chi^{2}=9,51\right.$, $\mathrm{P}=0,090, \mathrm{~N}=90)$, total parasitisasi $(\mathrm{F}=42,66, \mathrm{P}$ $\leq 0,001, \mathrm{~N}=90)$, jumlah telur yang tersisa dalam ovari $(\mathrm{F}=40,09, \mathrm{P} \leq 0,001, \mathrm{~N}=90)$ serta potensi produksi telur $(\mathrm{F}=10,91, \mathrm{P} \leq 0,001, \mathrm{~N}=90)$. Semakin lama $A$. nilaparvatae tidak mendapatkan inang, jumlah telur yang diletakkan dan tingkat parasitisasi A. nilaparvatae di hari pertama semakin menurun. Hal yang sama terjadi pada keperidian, tetapi sebaliknya justru terjadi pada jumlah telur yang tersisa dalam ovari (Tabel 3 dan 4). Jumlah telur yang diletakkan dan tingkat parasitisasi $A$. nilaparvatae di hari pertama menurun secara nyata setelah parasitoid tidak mendapatkan inang selama selama 9 jam dan semakin menurun seiring dengan semakin lamanya A. nilaparvatae tidak mendapatkan inang. Jumlah telur yang diletakkan A. nilaparvatae pada telur $N$. lugens lebih banyak di hari pertama dibandingkan dengan hari kedua

Tabel 1. Jumlah telur yang diletakkan Anagrus nilaparvatae pada telur Nilaparvata lugens di hari pertama dan kedua, keperidian, serta tingkat parasitisasi A. nilaparvatae di hari pertama dan kedua (perlakuan ketiadaan inang dengan pemberian pakan larutan madu $10 \%$ )

\begin{tabular}{lccccc}
\hline $\begin{array}{l}\text { Lama } \\
\text { ketiadaan } \\
\text { inang (jam) }\end{array}$ & $\begin{array}{c}{ }^{1} \text { Jumlah telur yang } \\
\text { diletakkan hari } \\
\text { pertama (telur) }\end{array}$ & $\begin{array}{c}{ }^{2} \text { Jumlah telur yang } \\
\text { diletakkan hari } \\
\text { kedua (telur) }\end{array}$ & $\begin{array}{c}{ }^{1} \text { Keperidian } \\
\text { (telur) }\end{array}$ & $\begin{array}{c}{ }^{1} \text { Tingkat } \\
\text { parasitisasi hari } \\
\text { pertama (\%) }\end{array}$ & $\begin{array}{c}{ }^{2} \text { Tingkat } \\
\text { parasitisasi hari } \\
\text { kedua }(\%)\end{array}$ \\
\hline 0 (kontrol) & $21,20 \pm 2,30 \mathrm{~d}$ & $2,13 \pm 1,55 \mathrm{~b}$ & $23,33 \pm 2,99 \mathrm{~d}$ & $27,55 \pm 5,26 \mathrm{~cd}$ & $2,74 \pm 1,95 \mathrm{~b}$ \\
3 & $21,87 \pm 2,29 \mathrm{~d}$ & $3,67 \pm 2,12 \mathrm{c}$ & $25,53 \pm 2,66 \mathrm{~d}$ & $29,41 \pm 4,54 \mathrm{~d}$ & $4,81 \pm 2,81 \mathrm{c}$ \\
6 & $21,07 \pm 2,12 \mathrm{~cd}$ & $1,73 \pm 1,16 \mathrm{~b}$ & $22,80 \pm 2,48 \mathrm{~cd}$ & $27,07 \pm 3,56 \mathrm{~cd}$ & $2,34 \pm 1,59 \mathrm{~b}$ \\
9 & $18,27 \pm 3,26 \mathrm{bc}$ & $1,53 \pm 1,72 \mathrm{~b}$ & $19,80 \pm 3,87 \mathrm{bc}$ & $23,72 \pm 5,09 \mathrm{bc}$ & $1,78 \pm 2,37 \mathrm{~b}$ \\
12 & $15,87 \pm 2,61 \mathrm{ab}$ & $1,13 \pm 1,45 \mathrm{ab}$ & $17,00 \pm 2,95 \mathrm{ab}$ & $19,60 \pm 3,76 \mathrm{ab}$ & $1,62 \pm 2,06 \mathrm{ab}$ \\
18 & $13,73 \pm 3,05 \mathrm{a}$ & $0,27 \pm 0,59 \mathrm{a}$ & $14,00 \pm 2,75 \mathrm{a}$ & $16,38 \pm 3,06 \mathrm{a}$ & $0,41 \pm 0,91 \mathrm{a}$ \\
\hline
\end{tabular}

${ }^{a}$ Angka-angka pada kolom yang sama yang diikuti oleh huruf yang sama tidak berbeda nyata pada taraf uji $5 \%$ ( ${ }^{1}$ uji Tukey, ${ }^{2}$ uji Mann-Whitney). Data disajikan dalam bentuk rataan $(\mathrm{X} \pm \mathrm{SD})$.

Tabel 2. Total parasitisasi Anagrus nilaparvatae, total nimfa Nilaparvata lugens yang muncul dan mati dalam padi, jumlah telur yang tersisa dalam ovari $A$. nilaparvatae, dan potensi produksi telur $A$. nilaparvatae (perlakuan ketiadaan inang dengan pemberian pakan larutan madu10\%)

\begin{tabular}{lccccc}
\hline $\begin{array}{l}\text { Lama ketiadaan } \\
\text { inang (jam) }\end{array}$ & $\begin{array}{c}{ }^{1} \text { Total parasitisasi } \\
(\%)\end{array}$ & $\begin{array}{c}{ }^{1} \text { Total nimfa } \\
\text {. lugens yang } \\
\text { muncul (\%) }\end{array}$ & $\begin{array}{c}\text { 2Total nimfa } N . \\
\text { lugens mati dalam } \\
\text { padi (\%) }\end{array}$ & $\begin{array}{c}\text { 'Jumlah telur } \\
\text { yang tersisa } \\
\text { dalam ovari } \\
\text { (telur) }\end{array}$ & $\begin{array}{c}{ }^{1} \text { Potensi produksi } \\
\text { telur (telur) }\end{array}$ \\
\hline 0 (kontrol) & $15,21 \pm 2,55 \mathrm{~cd}$ & $74,88 \pm 2,58 \mathrm{~b}$ & $9,88 \pm 1,43 \mathrm{a}$ & $11,40 \pm 2,77 \mathrm{a}$ & $34,73 \pm 4,04 \mathrm{a}$ \\
3 & $17,08 \pm 1,85 \mathrm{~d}$ & $72,10 \pm 1,83 \mathrm{a}$ & $10,78 \pm 1,35 \mathrm{a}$ & $14,67 \pm 3,15 \mathrm{ab}$ & $40,20 \pm 3,44 \mathrm{~b}$ \\
6 & $15,34 \pm 1,17 \mathrm{~d}$ & $74,54 \pm 2,10 \mathrm{~b}$ & $10,41 \pm 1,41 \mathrm{a}$ & $17,93 \pm 2,43 \mathrm{bc}$ & $40,67 \pm 3,73 \mathrm{~b}$ \\
9 & $13,17 \pm 2,46 \mathrm{bc}$ & $76,24 \pm 2,36 \mathrm{bc}$ & $10,57 \pm 1,13 \mathrm{a}$ & $21,00 \pm 2,64 \mathrm{~cd}$ & $40,80 \pm 3,14 \mathrm{~b}$ \\
12 & $11,25 \pm 2,10 \mathrm{~b}$ & $78,33 \pm 2,02 \mathrm{c}$ & $10,40 \pm 0,98 \mathrm{a}$ & $23,87 \pm 3,81 \mathrm{de}$ & $40,87 \pm 2,72 \mathrm{~b}$ \\
18 & $8,83 \pm 1,46 \mathrm{a}$ & $81,07 \pm 1,78 \mathrm{~d}$ & $10,04 \pm 1,09 \mathrm{a}$ & $26,73 \pm 4,33 \mathrm{e}$ & $40,73 \pm 2,86 \mathrm{~b}$ \\
\hline
\end{tabular}

${ }^{a}$ Angka-angka pada kolom yang sama yang diikuti oleh huruf yang sama tidak berbeda nyata pada taraf uji $5 \%\left({ }^{1}\right.$ uji Tukey, ${ }^{2}$ uji One-Way Anova). Data disajikan dalam bentuk rataan $(\mathrm{X} \pm \mathrm{SD})$. 
begitu pun tingkat parasitisasi di hari pertama lebih tinggi dibandingkan dengan hari kedua. Di hari pertama $A$. nilaparvatae meletakkan telur paling banyak pada perlakuan ketiadaan inang selama 3 jam dan paling sedikit pada perlakuan ketiadaan inang selama 18 jam (Tabel 3). Potensi produksi telur $A$. nilaparvatae meningkat setelah A. nilaparvatae tidak mendapatkan inang selama 3 jam selanjutnya cenderung tetap (Tabel 4). Parasitisasi $A$. nilaparvatae lebih rendah dibandingkan dengan parasitisasi $A$. nilaparvatae yang diberi pakan larutan madu $10 \%$ selama periode ketiadaan inang.

\section{Lama hidup imago parasitoid betina \\ A. nilaparvatae}

Lama ketiadaan inang mempengaruhi lama hidup imago parasitoid betina baik pada parasitoid yang diberi pakan larutan madu $10 \%\left(\chi^{2}=29,47\right.$, $\mathrm{P} \leq 0,001, \mathrm{~N}=90)$ maupun air $\left(\chi^{2}=33,19, \mathrm{P} \leq\right.$ $0,001, N=90)$. Lama hidup imago parasitoid betina meningkat secara signifikan pada lama ketiadaan inang 9 jam dan setelahnya, yaitu pada 12 dan 18 jam tidak mendapatkan inang pada kedua perlakuan pakan. Imago parasitoid betina hidup paling lama pada perlakuan ketiadaan inang selama 9 jam dan hidup paling singkat pada perlakuan ketiadaan inang selama 18 jam. Parasitoid betina mampu hidup lebih lama ketika mengkonsumsi larutan madu 10\% dibandingkan air (Gambar 3 dan 4).

\section{PEMBAHASAN}

Parasitoid betina A. nilaparvatae termasuk parasitoid tipe proovigenik karena memiliki telur yang sudah matang di awal kehidupan dewasanya. Telur matang parasitoid Mymarid berbentuk elips, seperti sosis dilengkapi dengan pedunculus yang panjang. Telur yang belum matang tidak diengkapi dengan pedunculus (Cronin \& Strong 1990).

Tabel 3. Jumlah telur yang diletakkan Anagrus nilaparvatae pada telur Nilaparvata lugens di hari pertama dan kedua, keperidian, serta tingkat parasitisasi A. nilaparvatae di hari pertama dan kedua (perlakuan ketiadaan inang dengan pemberian pakan air)

\begin{tabular}{lccccc}
\hline $\begin{array}{l}\text { Lama } \\
\text { ketiadaan } \\
\text { inang (jam) }\end{array}$ & $\begin{array}{c}\text { 'Jumlah telur yang } \\
\text { diletakkan hari } \\
\text { pertama (telur) }\end{array}$ & $\begin{array}{c}{ }^{2} \text { Jumlah telur yang } \\
\text { diletakkan hari } \\
\text { kedua (telur) }\end{array}$ & $\begin{array}{c}{ }^{1} \text { Keperidian } \\
\text { (telur) }\end{array}$ & $\begin{array}{c}{ }^{1} \text { Tingkat } \\
\text { parasitisasi hari } \\
\text { pertama (\%) }\end{array}$ & $\begin{array}{c}{ }^{2} \text { Tingkat } \\
\text { parasitisasi hari } \\
\text { kedua (\%) }\end{array}$ \\
\hline 0 & $21,07 \pm 3,03 \mathrm{c}$ & $1,40 \pm 2,23 \mathrm{a}$ & $22,40 \pm 3,24 \mathrm{c}$ & $26,84 \pm 5,35 \mathrm{~d}$ & $1,45 \pm 2,50 \mathrm{a}$ \\
3 & $21,27 \pm 1,75 \mathrm{c}$ & $0,33 \pm 0,90 \mathrm{a}$ & $21,53 \pm 2,10 \mathrm{c}$ & $27,38 \pm 4,38 \mathrm{~d}$ & $0,42 \pm 1,15 \mathrm{a}$ \\
6 & $20,53 \pm 2,26 \mathrm{c}$ & $0,47 \pm 1,24 \mathrm{a}$ & $21,00 \pm 2,23 \mathrm{c}$ & $26,40 \pm 4,68 \mathrm{c}$ & $0,62 \pm 1,63 \mathrm{a}$ \\
9 & $16,53 \pm 2,56 \mathrm{~b}$ & $0,20 \pm 0,77 \mathrm{a}$ & $16,73 \pm 2,54 \mathrm{~b}$ & $21,49 \pm 4,28 \mathrm{~b}$ & $0,28 \pm 1,10 \mathrm{a}$ \\
12 & $14.87 \pm 2,03 \mathrm{ab}$ & $0,33 \pm 0,72 \mathrm{a}$ & $15,13 \pm 2,32 \mathrm{ab}$ & $17,38 \pm 3,06 \mathrm{ab}$ & $0,32 \pm 0,74 \mathrm{a}$ \\
18 & $12,40 \pm 2,99 \mathrm{a}$ & $0,20 \pm 0,56 \mathrm{a}$ & $12,60 \pm 2,99 \mathrm{a}$ & $14,35 \pm 3,23 \mathrm{a}$ & $0,24 \pm 0,67 \mathrm{a}$ \\
\hline
\end{tabular}

${ }^{a}$ Angka-angka pada kolom yang sama yang diikuti oleh huruf yang sama tidak berbeda nyata pada taraf uji $5 \%$ ( ${ }^{1}$ uji Tukey, ${ }^{2}$ uji Kruskal-Wallis). Data disajikan dalam bentuk rataan $(\mathrm{X} \pm \mathrm{SD})$.

Tabel 4. Total parasitisasi A. nilaparvatae, total nimfa $N$. lugens yang muncul dan mati dalam padi, jumlah telur yang tersisa dalam ovari A. nilaparvatae, dan potensi produksi telur A. nilaparvatae (perlakuan ketiadaan inang dengan pemberian pakan air)

\begin{tabular}{lccccc}
\hline $\begin{array}{l}\text { Lama ketiadaan } \\
\text { inang (jam) }\end{array}$ & $\begin{array}{c}{ }^{1} \text { Total parasitisasi } \\
(\%)\end{array}$ & $\begin{array}{c}{ }^{1} \text { Total nimfa } \\
\text { N. lugens yang } \\
\text { muncul (\%) }\end{array}$ & $\begin{array}{c}{ }^{2} \text { Total nimfa } \\
\text { N. lugens mati } \\
\text { dalam padi (\%) }\end{array}$ & $\begin{array}{c}{ }^{1} \text { Jumlah telur yang } \\
\text { tersisa dalam ovari } \\
\text { (telur) }\end{array}$ & $\begin{array}{c}{ }^{1} \text { Potensi produksi } \\
\text { telur (telur) }\end{array}$ \\
\hline 0 (kontrol) & $15,40 \pm 2,72 \mathrm{c}$ & $74,07 \pm 3,10 \mathrm{a}$ & $10,46 \pm 1,06 \mathrm{a}$ & $11,07 \pm 2,71 \mathrm{a}$ & $33,47 \pm 3,13 \mathrm{a}$ \\
3 & $15,11 \pm 1,72 \mathrm{c}$ & $74,59 \pm 1,83 \mathrm{ab}$ & $10,22 \pm 0,50 \mathrm{a}$ & $15,20 \pm 3,32 \mathrm{ab}$ & $36,73 \pm 4,52 \mathrm{ab}$ \\
6 & $14,12 \pm 1,94 \mathrm{c}$ & $75,38 \pm 1,90 \mathrm{~b}$ & $10,48 \pm 0,79 \mathrm{a}$ & $19,40 \pm 3,86 \mathrm{~b}$ & $40,40 \pm 3,01 \mathrm{~b}$ \\
9 & $11,12 \pm 1,49 \mathrm{~b}$ & $78,40 \pm 2,56 \mathrm{c}$ & $10,44 \pm 0,62 \mathrm{a}$ & $23,87 \pm 4,12 \mathrm{c}$ & $40,60 \pm 3,81 \mathrm{~b}$ \\
12 & $9,66 \pm 1,45 \mathrm{ab}$ & $80,13 \pm 1,56 \mathrm{~cd}$ & $10,18 \pm 0,92 \mathrm{a}$ & $25,53 \pm 4,54 \mathrm{~cd}$ & $40,67 \pm 3,24 \mathrm{~b}$ \\
18 & $7,75 \pm 1,58 \mathrm{a}$ & $81,70 \pm 1,92 \mathrm{~d}$ & $10,52 \pm 0,72 \mathrm{a}$ & $28,13 \pm 4,96 \mathrm{~d}$ & $40,73 \pm 3,30 \mathrm{~b}$ \\
\hline
\end{tabular}

${ }^{\mathrm{a} A n g k a-a n g k a ~ p a d a ~ k o l o m ~ y a n g ~ s a m a ~ y a n g ~ d i i k u t i ~ o l e h ~ h u r u f ~ y a n g ~ s a m a ~ t i d a k ~ b e r b e d a ~ n y a t a ~ p a d a ~ t a r a f ~ u j i ~} 5 \%$ ( ${ }^{1}$ uji Tukey,

${ }^{2}$ uji One-Way Anova). Data disajikan dalam bentuk rataan $(\mathrm{X} \pm \mathrm{SD})$. 




Gambar 3. Rata-rata lama hidup imago parasitoid betina Anagrus nilaparvatae yang diberi pakan larutan madu $10 \%$. Huruf yang sama di atas diagram tidak berbeda nyata pada taraf $5 \%$ (uji MannWhitney).

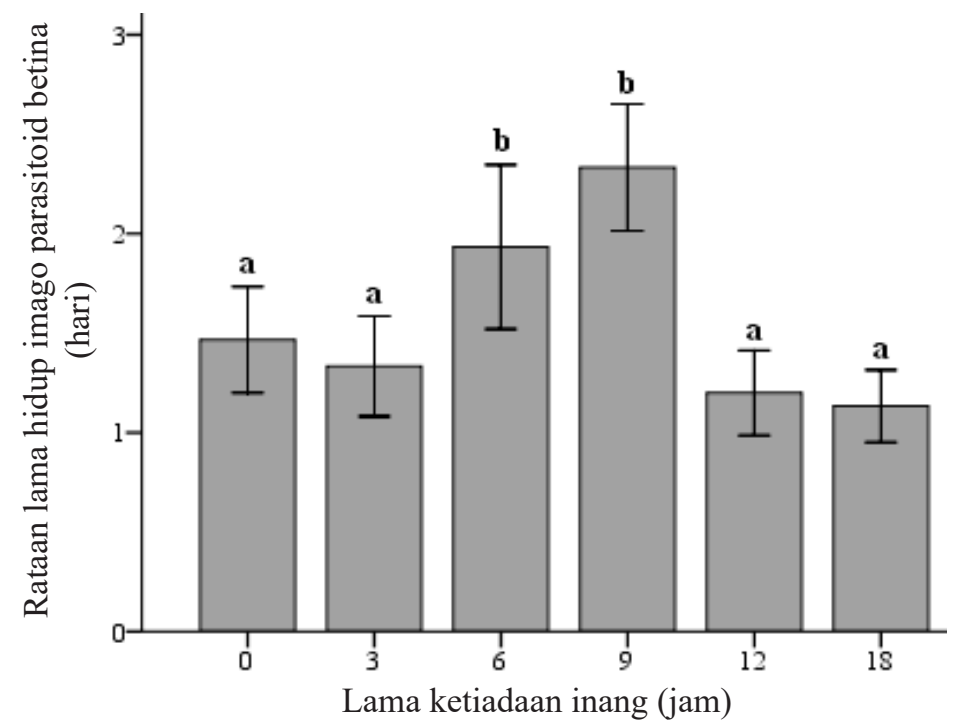

Gambar 4. Rata-rata lama hidup imago parasitoid betina Anagrus nilaparvatae yang diberi pakan air. Huruf yang sama di atas diagram tidak berbeda nyata pada taraf 5\% (uji Mann-Whitney).

Parasitoid A. nilaparvatae tidak termasuk synovigenik walaupun produksi telur matang masih terjadi di masa hidup dewasanya. Hal tersebut disebabkan oleh produksi telur matang tidak terjadi selama masa hidup dewasanya, namun hanya hingga beberapa saat saja, yakni sampai 3 jam sejak kemunculannya sebagai imago. Produksi telur matang selanjutnya cenderung tetap (sampai 18 jam). Flanders (1950) melaporkan bahwa produksi telur matang pada spesies parasitoid proovigenik yang tidak sepenuhnya selesai sebelum oviposisi dimulai, penambahan telur dapat terjadi beberapa saat setelah parasitoid keluar dari inang (Flanders 1950). Chantarasa-ard et al. (1984) melaporkan bahwa produksi telur pada beberapa parasitoid betina Anagrus incarnatus Haliday (proovigenik) masih berlanjut selama masa hidup dewasa ketika parasitoid diberi pakan madu dan dipelihara pada $20^{\circ} \mathrm{C}$.

Penurunan keperidian dan tingkat parasitisasi A. nilaparvatae tidak disebabkan oleh resorpsi telur (oosorption), seperti terlihat dari potensi produksi telur yang mengalami peningkatan setelah 3 jam tanpa inang selanjutnya cenderung tetap. Parasitoid proovigenik umumnya hidup singkat dan tidak memiliki kemampuan menyerap kembali telur yang telah diproduksi (Flanders 1950; Mutitu et al. 2013). 
Penelitian ini menunjukkan adanya pengaruh ketiadaan inang terhadap perubahan perilaku betina $A$. nilaparvatae dalam oviposisi. Betina $A$. nilaparvatae yang terlalu lama tidak memperoleh inang akan meletakkan telur-telurnya lebih sedikit daripada betina $A$. nilaparvatae yang menemukan inang sejak awal kemunculannya sebagai imago. Perubahan perilaku oviposisi menjadi lebih rendah mungkin dipengaruhi oleh stimulus pendorong oviposisi(Akbar \& Buchori2012). Ketiadaan inang yang terlalu lama akan membuat betina parasitoid gagal menanggapi rangsangan oviposisi (Navasero \& Elzen 1992) yang disebabkan penerimaan stimulus kemosensorik dari inang menjadi menurun (Herrebout 1969). Penerimaan stimulus kemosensorik dari inang semakin melemah dengan bertambahnya usia betina parasitoid seiring meningkatnya periode ketiadaan inang (Amalin et al. 2005) yang selanjutnya dapat mempengaruhi perilaku dalam menemukan dan menangani inang (Fleury \& Bouletreau 1993). Ketiadaan inang yang terlalu lama juga mungkin menyebabkan betina parasitoid menjadi tidak berpengalaman dalam oviposisi yang berdampak pada penurunan dalam penanganan inang (Drost \& Carde 1992) sehingga kemampuan peletakan telurnya menjadi rendah akibatnya keperidian dan tingkat parasitisasinya pun rendah, sebaliknya telur yang tersisa dalam ovari parasitoid semakin banyak. Jadi, meskipun potensi produksi telur tinggi, tetapi dengan tingkat parasitisasi rendah, kemampuan mengendalikan inang juga terpengaruh.

Jumlah telur yang diletakkan A. nilaparvatae pada telur $N$. lugens lebih banyak di hari pertama dibandingkan hari kedua akibatnya tingkat parasitisasi di hari pertama lebih tinggi dibandingkan dengan hari kedua. Parasitoid akan memaksimumkan peletakan telurnya di hari pertama kali mendapatkan inang dan menurun pada hari berikutnya (Tarla 2011). Ketiadaan inang selama 3 jam meningkatkan produksi telur dan stimulus pendorong untuk oviposisi masih bekerja dengan baik sehingga laju penerimaan inang meningkat (Akbar \& Buchori 2012). Penerimaan inang oleh parasitoid ditunjukan dengan parasitoid meletakkan telurnya dalam inang tersebut. Parasitoid meletakkan telurnya dalam inang berarti terjadi parasitisasi (Li et al. 1994). Implikasi dari hasil penelitian ini adalah semakin lama A. nilaparvatae tidak mendapatkan inang akan mengubah perilaku $A$. nilaparvatae dalam meletakkan telur. Parasitoid A. nilaparvatae akan meletakkan telurnya lebih sedikit jika sebelumnya parasitoid terlalu lama tidak mendapatkan inang (telur $N$. lugens) akibatnya telur $N$. lugens yang menetas menjadi nimfa jumlahnya akan semakin banyak (Tabel 2 dan 4).

Potensi produksi telur pada parasitoid proovigenik adalah tetap dan ditentukan pada saat pertama kali keluar dari inang sebagai imago (Aung et al. 2010). Namun, produksi telur matang (oogenesis) A. nilaparvatae dari hasil penelitian ini tampaknya masih berlangsung sampai dengan 3 jam setelah keluar dari inang sebagai imago. Jumlah telur matang A. nilaparvatae setelah 3 jam cenderung tetap. Flanders (1950) menyatakan bahwa pada spesies proovigenik, oogenesis yang tidak sepenuhnya selesai sebelum oviposisi dimulai, deposisi telur terjadi dalam beberapa saat setelah parasitoid keluar dari inang.

Pakan madu menyediakan nutrisi penting bagi parasitoid terutama karbohidrat sebagai sumber energi. Madu akan dicerna dalam tubuh parasitoid dan dapat meningkatkan metabolisme tubuh. Metabolisme yang semakin baik dapat meningkatkan keaktifan parasitoid dalam bergerak mencari inang, berkopulasi, dan memarasit (Mutitu et al. 2013).

Lama ketiadaan inang sampai 9 jam tampaknya membuat imago parasitoid betina menyimpan lebih banyak energi karena hanya sedikit melakukan oviposisi dibandingkan dengan imago betina yang langsung mendapatkan inang di awal kehidupan dewasanya (Handayani et al. 2004). Energi tersebut lebih digunakan untuk memelihara metabolisme tubuh sehingga dapat hidup lebih lama (Cronin \& Strong 1990). Hohmann \& Luck (2004) melaporkan bahwa parasitoid yang tidak diberi inang atau diberi inang terbatas selama hidupnya mampu hidup lebih lama dibandingkan dengan parasitoid yang diberikan inang tanpa batas setiap hari selama hidupnya. Madu merupakan sumber karbohidrat di kebanyakan serangga yang dicerna dalam tubuh sehingga menghasilkan energi. Energi dapat digunakan untuk memelihara metabolisme dalam tubuh. Metabolisme tubuh yang terpelihara dengan baik dapat meningkatkan lama hidup (Mutitu et al. 2013). Peningkatan lama 
hidup penting untuk menghadapi kondisi inang yang langka atau jarang di alam sampai parasitoid menemukan inangnya.

Hasil penelitian ini menunjukkan bahwa pemantauan terhadap fase $N$. lugens di lapangan sebelum pelepasan menjadi penting. Hal ini disebabkan keragaan $A$. nilaparvatae yang akan cepat menurun jika dalam waktu 9 jam tidak menemukan inang. Pakan madu penting untuk mendukung kinerja parasitoid dalam memarasit inang dan meningkatkan lama hidup. Pakan madu di alam dapat diupayakan dengan mempertahankan rerumputan liar di pematang sawah dan tumbuhan liar berbunga di sekitar lahan sebagai penghasil nektar.

\section{KESIMPULAN}

Tipe peneluran A. nilaparvatae adalah proovigenik. Pematangan telur A. nilaparvatae sudah diawali sejak parasitoid keluar dari inang sebagai imago (dewasa). Parasitoid betina $A$. nilaparvatae memiliki telur yang sudah matang di awal kehidupan dewasanya sebanyak $75 \%$ dari potensi produksi telur. Ketiadaan inang selama 9 jam sampai 18 jam dalam kondisi tersedia larutan madu $10 \%$ maupun air dapat menurunkan keragaan reproduksi parasitoid A. nilaparvatae, meliputi keperidian, tingkat parasitisasi, dan lama hidup imago betina. Lama ketiadaan inang dengan pemberian pakan larutan madu $10 \%$ menurunkan keperidian A. nilaparvatae sebesar 15,13\% (9 jam), 27,13\% (12 jam), dan 39,99\% (18 jam) serta menurunkan total parasitisasi sebesar 13,41\% (9 jam), 26,03\% (12 jam), dan 41,94\% (18 jam). Lama ketiadaan inang dengan pemberian pakan air menurunkan keperidian A. nilaparvatae sebesar $25,31 \%$ ( 9 jam), 32,45\% (12 jam), dan 43,75\% (18 jam) serta menurunkan total parasitisasi sebesar 27,20\% (9 jam), 37,27\% (12 jam), dan 49,67\% (18 jam). Penurunan keperidian dan parasitisasi A. nilaparvatae selama periode ketiadaan inang lebih tinggi pada perlakuan pemberian pakan air daripada larutan madu $10 \%$.

\section{DAFTAR PUSTAKA}

Akbar ME, Buchori D. 2012. Pengaruh lama ketiadaan inang terhadap kapasitas reproduksi parasitoid Snellenius manilae Ashmead (Hymenoptera: Braconidae). Jurnal Entomologi Indonesia 9:14-22. doi: https://doi.org/10.5994/ jei.9.1.14.

Amalin DM, Pena JE, Duncan RE. 2005. Effects of host age, female parasitoid age, and host plant on parasitism of Ceratogramma etiennei (Hymenoptera: Trichogrammatidae). Florida Entomologist 88:77-82. doi: https://doi. org/10.1653/0015-4040(2005)088[0077:EOHA FP]2.0.CO;2.

Meilin A. 2012. Dampak Aplikasi Insektisida pada Parasitoid Telur Wereng Batang Coklat dan Deltametrin Konsentrasi Subletal terhadap Anagrus nilaparvatae (Hymenoptera: Mymaridae). Disertasi. Yogyakarta: Universitas Gadjah Mada.

Aung KSD, Takagi M, Ueno T. 2010. Influence of food on the longevity and egg maturation of the egg parasitoid Ooencyrtus nezarae (Hymenoptera: Encyrtidae). Journal of the Faculty of Agriculture, Kyushu University 55:79-81.

Chantarasa-ard S, Hirashima Y, Miura T. 1984. Effects of temperature and food on the development and reproduction of Anagrus incarnatus Haliday (Hymenoptera: Mymaridae), an egg parasitoid of the rice planthoppers. Esakia 22:145-158.

Cronin JT, Strong DR. 1990. Biology of Anagrus delicatus (Hymenoptera: Mymaridae), an egg parasitoid of Prokelisia marginata (Homoptera: Delphacidae). Entomological Society of America 83:846-854. doi: https://doi.org/10.1093/ aesa/83.4.846.

Diani D, Atmadja WR, Kusdiaman D, Supriyadi. 1992. Komposisi parasitoid pada telur wereng (Nilaparvata lugens Stal.). Di dalam: Kongres Entomologi IV (Yogyakarta, 28-30 Januari 1992). Yogyakarta: Perhimpunan Entomologi Indonesia.

Drost YC, Carde RT. 1992. Influence of host deprivation on egg load and oviposition behaviour of Brachymeria inntermedia, a parasitoid of gypsy moth. Physiological Entomology 17:230-234. doi: https://doi. org/10.1111/j.1365-3032.1992.tb01015.x.

Flanders SE. 1950. Regulation of ovulation and egg disposal in the parasitic Hymenoptera. The Canadian Entomologist 82:134-140. doi: https:// doi.org/10.4039/Ent82134-6. 
Fleury F, Bouletreau M. 1993. Effects of temporary host deprivation on the reproductive potential of Trichogramma brassicae. Entomologia Experimentalis et Applicata 68:203-210. doi: https://doi.org/10.1111/j.1570-7458.1993. tb01705.x.

Handayani RS, Buchori D, Prijono D. 2004. Pengaruh pakan dan inang terhadap lama hidup dan produksi telur Trichogramma pretiosum Riley (Hymenoptera: Trichogrammatidae). Di dalam: Arifin et al. (Ed.), Prosiding Seminar Nasional Enlomologi dalam Perubahan Lingkungan dan Sosial (Bogor, 5 Oktober 2004). hlm. 45-60. Bogor: IPB.

Herrebout WM. 1969. Habitat selection in Eucarcelia rutilla Vill. (Diptera: Tachinidae) experiments with females of known age. Zeitschrift Fur Angewandte Entomologie 63:336-349. doi: https://doi.org/10.1111/j.1439-0418.1969. tb04390.x.

Hohmann CL, Luck RF. 2004. Effect of host availability and egg load in Trichogramma platneri Nagarkatti (Hymenoptera: Trichogrammatidae) and its consequences on progeny quality. Brazilian Archives of Biology and Technology .47:413-422. doi: http://dx.doi. org/10.1590/S1516-89132004000300012.

Kant R, Minor M, Trewick S, Sandanayaka M. 2013. Effects of mating and oviposition delay on parasitism rate and sex allocation behaviour of Diaeretiella rapae (Hymenoptera: Aphidiidae). Biological Control 65:265-270. doi: https://doi. org/10.1016/j.biocontrol.2013.01.012.

Kapranas A, Luck RF. 2008. Egg maturation, host feeding, and longevity in two Metaphycus parasitoids of soft scale insects. Biological Control 47:147-153. doi: https://doi. org/10.1016/j.biocontrol.2008.08.002.

Navasero R, Elzen G. 1992. Influence of maternal age and host deprivation on egg production and parasitization by Microplitis croceipes (Hym: Braconidae). Entomophaga 37:37-44. doi: https://doi.org/10.1007/BF02372972.

Papaj DR. 2000. Ovarian dynamics and host use. Annual Review of Entomology 45:423-448. doi: https://doi.org/10.1146/annurev.ento.45.1.423.

Kartohardjono A. 2011. Penggunaan musuh alami sebagai komponen pengendalian hama padi berbasis ekologi. Pengembangan Inovasi Pertanian 4:29-46.
Li SY, Henderson DE, Myers JH. 1994. Selection of suitable Trichogramma spesies for potential control of the blackheaded fireworm infesting cranberries. Biological Control 4:244-8. doi: https://doi.org/10.1006/bcon.1994.1030.

Meilin A, Trisyono YA, Martono E, Buchori D. 2012. The effects of Deltamethrin applied at sublethal concentrations on the adults of Anagrus nilaparvatae (Hymenoptera: Mymaridae). ARPN Journal of Agricultural and Biological Science. 12:1032-1037.

Mutitu EK, Bush SJ, Garnas JR, Harney M, Hurley BP, Wingfield MJ, Slippers B. 2013. Biology and rearing of Cleruchoides noackae (Hymenoptera: Mymaridae), an egg parasitoid for the biological control of Thaumastocoris peregrinus (Hemiptera: Thaumastocoridae). Journal of Economic Entomology 106:1979-1985. doi: https://doi. org/10.1603/EC13135.

Tarla S. 2011. Impact of host deprivation on the reproductive potential of the egg parasitoid Trissolcus grandis Thompson (Hymenoptera: Scelionidae). Egyptian Journal Biological Pest Control 21:111-117.

Savino V, Coviella CE, Luna MG. 2012. Reproductive biology and functional response of Dineulophus phtorimaeae, a natural enemy of the tomato moth, Tuta absoluta. Journal of Insect Science 153:114. doi: https://doi.org/10.1673/031.012.15301.

Santolamazza CS, Cordero RA. 2003. Egg load and adaptive superparasitism in Anaphes nitens Girault (Hymenoptera: Mymaridae), an egg parasitoid of the eucalyptus snout beetle Gonipterus scutellatus Gyllenhal (Coleoptera: Curculionidae). Entomologia Experimentalis et Applicata 106:127-134. doi: https://doi. org/10.1046/j.1570-7458.2003.00011.x.

Xiang C, Ren N, Wang X, Sumera A, Cheng J, Lou Y. 2008. Preference and performance of Anagrus nilaparvatae (Hymenoptera: Mymaridae): effect of infestation duration and density by Nilaparvata lugens (Homoptera: Delphacidae). Environmental Entomology 37:748-754. doi: https://doi.org/10.1093/ee/37.3.748. 